\title{
探讨建筑工程施工技术管理现状及相应对策
}

\author{
袁永涛 \\ 天津天一建设集团有限公司 \\ DOI:10.18686/bd.v1i12.1126
}

[摘 要] 建筑施工是一个非常复杂的过程。建筑施工技术的管理非常重要, 是施工项目管理的重要组成部分。通过建筑施 工技术管理, 可以大幅度降低工程施工成本, 提高工程施工质量, 避免安全事故发生。需要解决建设项目建设中存在的问题, 加强建设工程技术管理的多方面。

[关键词] 建筑工程施工技术管理; 问题; 措施

随着社会主义市场经济的发展和改革开放的不断推 进,我国工程建筑业正进人一个黄金发展时期。为了过分强 调经济效益的重要性, 一些公司忽视了施工技术管理的重 要作用,造成事故频发。这不仅给企业和国家带来财产损失, 公司因此降低了招标的资格,也给伤亡家属造成沉重打击。 要充分认识到建筑施工技术管理的重要性, 及时检查, 不断 积累经验,为施工质量提供有力保障。

\section{1 建筑工程施工技术管理认识}

建筑工程施工技术管理,是指以系统论的观点,对构成 施工技术的各项要素和施工企业的各项技术活动, 运用科 学方法,进行计划与决策、组织与指挥、控制与调节。众所周 知, 建筑工程的施工是一种复杂的多工种协同操作、多项技 术交叉综合应用的过程。这就决定了施工企业的技术活动 也是多种多样的。这里所指的“技术活动”, 包括熟悉与会审 图样、编制施工组织设计, 施工过程中的商洽管理、建筑工 程质量检验和竣工验收等全过程中的技术工作。“施工技术 的各项要素” 是指各项技术活动赖以进行的技术标准与规 程、技术情报、技术装备、技术人才以及技术责任等等。

\section{2 建筑工程施工技术管理现状}

目前, 我国建筑工程施工公司的技术管理工作还处于 粗放式管理,没有系统化的施工技术管理体系,单纯依靠施 工技术管理的质量管理和文件归档。另外,由于中标后分包 施工, 中标人员缺乏对分包公司的技术管理, 也使现代施工 项目难以开展技术管理,影响了施工技术管理的科学发展。 最后, 施工技术管理实施不到位, 粗放管理影响了施工技术 管理,导致施工过程的技术管理不能为质量管理,成本管理 等管理工作提供良好的基础, 影响正常的施工管理发展已 经影响到施工企业综合市场竞争力的提高。针对这种情况, 加快了对施工工程技术管理的分析研究, 提高了施工企业 技术管理意识,提升了施工企业技术管理水平。这为提高施 工企业的综合市场竞争力奠定了基础,并成为现代企业。建 筑工程施工企业面临的最重要的问题。

\section{3 建筑施工技术管理意义}

建筑施工技术的管理意味着按照系统论的理念, 通过 运用科学实践,制定合理的决策方案, 积极组织和指导施工
技术的各种要素和技术活动并有效地控制和协调。在施工 过程中, 所有技术工作应按照国家制定的相应技术规范和 法律法规进行, 以确保整个生产过程符合规范和法规。建筑 施工技术管理意义主要表现为以下几方面。

\section{1 施工技术管理贯穿于建筑施工全过程}

建筑施工技术的管理始终贯穿整个施工过程。从确认 建设项目和签订合同直至项目完成, 技术管理工作始终涉 及贯穿各个阶段。另外,由于施工工程是一个复杂而复杂的 多工序,多工序,多技术协调配合的过程,施工工艺的应用极 其复杂。不仅需要对图纸进行审查和构建。组织设计准备, 现场施工组织管理, 质量检验验收等工作, 还应充分熟悉和 了解相关技术标准和规定, 技术资料以及技术装备的使用 情况。

3.2 施工技术管理水平的高低影响重大

建筑施工企业建设项目的主要目的是获得可观的效 益,施工技术管理水平直接决定了这一目标是否达到。同时, 施工技术管理水平直接影响到工程质量,进度,成本等方面。 不同的建筑物, 其造型设计, 建筑规模等方面也存在一定差 异,受建筑条件,环境,人为因素等因素影响不尽相同,因此, 必须加强施工技术管理, 以确保建筑工程的有序建设达到 预期要求,达到企业获得经济效益和社会效益的主要目的。

3.3 施工技术管理水平重要作用

进行建筑施工技术管理主要有以下几点作用: 一是有 助于提高施工项目参与人员的安全施工意识, 提高施工技 术人员的专业技能,使问题及时有效地得到解决; 确保施工 严格按照施工图纸和施工技术要求进行, 确保施工质量和 进度; 三是帮助施工人员充分发挥他们的才能和作用,最大 限度地利用人力,工程机械设备和材料的价值,从而合理降 低工程造价,提高公司的经济效益和社会效益。

\section{4 建筑工程技术管理存在问题及相应改善意见}

4.1 建筑工程现场施工技术管理存在的问题

4.1.1 现场安全管理有待加强

在建筑工程施工现场, 安全问题是影响工程施工进展 的关键因素,安全问题至关重要。当前,大部分建筑工程施工 现场普遍存在的安全问题有三点: 
4.1.1.1 监督管理机构安全管理不到位, 部分施工单位 甚至没有在施工现场建立统一的监督管理机构。部分施工 单位的监督管理机构在开展安全管理工作中涉及多部门合 作,但协同管理标准不一致,导致管理工作实施权威缺乏。

4.1.1.2 国内对建筑工程建设安全管理工作重视度不 足,相关的法制法规不健全, 以致建筑工程施工现场的安全 管理工作无法可依,安全管理工作法规有待完善。

4.1.1.3 建设工程施工单位领导对安全管理工作重视不 够, 在项目开工前不进行必要的安全培训。整个施工单位和 施工队伍的安全意识比较薄弱。一旦建筑工程施工现场发 生安全事故,就没有统一的安全措施。事故处理标准和应急 措施严重影响了施工现场的安全管理水平。

\subsection{2 现场人员管理不到位}

建设工程现场施工技术管理的不足也与施工现场技术 管理人员的管理水平有关。现阶段,施工现场施工人员缺乏 管理主要是管理人员管理素质偏低所致。近年来,国内建筑 工程行业进人高速发展时期,发展速度过快,导致建筑业各 方面的管理工作与建设进度不相适应。管理工作落后于施 工工作和现场施工技术管理工作。不到位是主要方面之一。 缺乏现场施工和技术管理首先表现为管理人员忽视施工技 术人员的选拔,造成大量临时工参与施工。临时工缺乏施工 专业知识, 安全意识薄弱, 对建设项目造成隐患安全隐患。现 场人员的不完整管理将直接影响技术管理的整体水平,增 加施工难度,影响项目进度。

\subsection{3 现场进度管理较混乱}

建筑工程在高速发展期, 建筑工程施工中赶工期的现 象屡见不鲜, 同时在建筑工程施工中缺乏科学的进度管理, 这影响了项目建设各方面的进度和管理, 导致了施工现场 的混乱。现场进度管理是项目进度管理的重要组成部分。在 现场进度管理中,应包括项目设计和管理计划的进度,材料 的使用进度和进度计划中的事故, 以形成施工现场管理情 况。但在实际建筑施工中,现场施工管理一直是现场施工管 理工作中的薄弱环节。应该根据时间表加强和完善项目进 度管理。

4.2 提高房屋建筑工程施工技术管理对策

4.2.1 建立优质的技术管理队伍

在建筑施工技术管理过程中, 首先要建立一支高素质 的技术管理队伍, 技术管理人员的素质直接关系到施工能 否顺利进行和施工质量问题。在施工的初期,要建立技术管 理队伍,充分保证技术管理水平。要根据工程的具体实践,结 合工程技术的标准和要求编制具体管理方案, 要对管理职
责进行分配,从而做到权责分明,要协调好施工人员、技术人 员和技术管理人员的关系,把工作任务进行细化处理,从而 逐层进行技术交底工作, 保证施工人员可以切实了解工作 的内容、严格控制技术的使用, 从而保证工程的进度和质 量。此外,我们还必须确保技术管理团队拥有高素质的技术 顾问。我们必须确保技术顾问对现代新技术和新技术有充 分的了解。只有这样才能有效地指导施工人员。

\subsection{2 制定严格的技术管理规范}

在施工技术管理过程中, 要制定严格的技术管理规范, 严格控制施工人员的技术应用, 防止因技术应用不合规导 致工程质量问题。对建筑工程各个施工环节进行详细的技 术处理,防止施工过程中存在安全隐患。此外,施工技术管理 规范可以确保工程问题可以根据证据进行处理。如果出现 技术应用问题, 可以从技术管理规范进行协调, 以防止损害 项目建设效益。

\subsection{3 严格控制施工质量和工期}

施工技术管理的最终目标是确保施工的质量和持续时 间,防止施工质量,并延误施工造成的损害项目效益。因此施 工过程中必须严格控制施工质量和进度。在施工质量控制 的要求下,要对施工材料和施工人员进行管理,防止施工材 料不符合工程建设标准。一旦出现重大问题,无论施工技术 多么先进,都难以保证项目建设的质量。另外,要有效提高施 工人员的素质, 必须对施工人员进行施工前的培训,使施工 人员有一定的施工作业。对于施工期的控制, 有必要在技术 管理中组织和规划施工,细化施工任务,使施工任务可以在 各个层次上实施, 以协调工程进度和确保住房项目的顺利 建设。落实和提高项目建设的效益水平。

\section{5 结束语}

而建筑施工技术的管理作为工程管理中的一项基础性 的工作,在建筑业尤其是房地产业蓬勃发展的今天,建筑行 业竞争日益加剧, 大中小建筑企业如雨后春笋般的出现,施 工技术管理在保障工程建设进度与工程质量方面发挥着重 要地促进作用, 通过加强建筑施工技术管理是建筑企业提 高市场竞争力的最为直接最为有效途径。

\section{参考文献:}

[1]李晓波.浅谈述建筑施工技术优化管理[J]现代装饰 (理论),2017,(01):44.

[2]欧敏.建筑工程管理困境及解决措施[J].建材与装 饰,2018,(03):164.

[3]夏丽萍.浅析建筑工程现场施工技术管理 [J].四川 水泥,2018,(02):125. 